\title{
System of informational support for the targeted development of the educational space of the region as a tool of the competitiveness growth
}

\author{
Valeriy V. Poluboyarov \\ Volgograd State University, \\ Department of IT Support and Telecommunications \\ Volgograd, Russia \\ vvp@volsu.ru
}

\author{
Alla E. Kalinina \\ Volgograd State University, \\ Administration of the University, \\ Volgograd, Russia \\ ns.mironova@yandex.ru
}

\begin{abstract}
The relevance of use of management system by objects in a higher educational institution is proved. The approaches to the assessment of scientific, research and educational activity in an educational institution are studied. The indices for the assessment of scientific, research and educational activity are chosen. The analysis of platforms of informational management support by objectives is carried out. The conclusion about the absence of the ready made solution which can be recommended to all the higher educational institutions is made. The experience of the introduction of the system of informational support of management by objectives in the Volgograd State University is described.
\end{abstract}

Keywords - management system by objectives, university, indicators of research and educational activities, platform for informational support of management by objectives

\section{INTRODUCTION}

The necessity to react quickly on social and economic changes in the environment has lead to a wide introduction into the managerial practice of higher education of the elements of the system of strategic management: mission, vision, strategic goals, strategy and so on [1]. Many Russian higher educational institutions introducing into their activity the strategic management [2] become in fact regional university centers and drivers of the regional development.

The university can contribute to the growth of competitiveness and investment attractiveness of a region by means of the solution of the tasks of its innovation development, via the organization of new innovative infrastructure objects, business incubators for perspective projects, popularization of technological entrepreneurship, implementation of educational programs and projects in the sphere of technological, social entrepreneurship and innovation activity. The solution of the tasks of technological development of the region by university centers is possible by means of the following actions: expansion of the sphere of use of R\&D skills of students and scientists in the directions and technologies suggested in the National technological initiative in the association with enterprises of the region and development institutes; development and modernization of basic and supplementary educational programs, their implementation on the basis of digital online platforms. And of course technological and innovative development of a region is impossible without such an important component of social development as the involvement of the youth into the social entrepreneurship and into the creation of corresponding skills. It is impossible also without the implementation of humanitarian projects in the sphere of moral patriotic building, education, social security and ecology; without the creation of new socially focused non profit organizations; of the development of volunteer movement; without the creation of creative sphere of social innovations formation.

The target goals for higher educational institutions in the regional development have found direct expression in the creation of university strategic plans and programs.

The approaches to the development of the strategic management system in Russian higher educational institutions can be divided into three main groups: on the basis of program and target approach, on the basis of the system of balanced indices, on the basis of the analysis of the university as an integrated two level system. Such a differentiation has a considerably conditional character and reflects some essential differences in the approaches to the development of the strategy of an educational institution conserving the harmony in the process logic and in the used tools [3].

The system of the management by objectives is a managerial approach which can be defined as a process of goal setting and criteria determination of employees efficiency, of separate divisions efficiency (or organization as a whole) and of the coordination of the efforts (resources) in their achievement [4]. Its modernization is presented by the system of balanced indices (BSC, Balanced Scorecard) [5] which include the changes of both financial and non financial character connected one with another (Client, Internal Processes, Growth and Development). The list of key efficiency indicators (Key Performance Indicator, KPI) corresponds to every of these measures. The peculiarity of the BSC approach is the integration of the methods of system and process approach to the management and to the provision of 
the relation between the motives of the employees and the efficiency of the work of the organization in the whole. The advantages of the BSC approach over the program and target method and the method of the university management as a complicated subject is the constructed hierarchy of goals, their coordination at all managerial levels, objective character of the criteria of labour assessment, feedback and the opportunity of the assessment and of the correction of the work of employees, divisions and organization as a whole. The advantages are presented by the costs for high temporal and financial expenses for development.

In order to take optimal solutions the management of a higher education institution is expected to get internal managerial information which allows controlling the internal business processes, personnel, demands of clients and educational market together with the financial statements [6]. The experience of use of BSC approach in the process of the university management is described in sources $[7,6,2,8,9$, 10]. Their authors suggest various lists of strategic goals, tasks and indices of the assessment of their efficiency. In the source [11] as the indices of the university activity efficiency the following measures are used: education, science, internationalization, sustainable development, connection with the region, interaction with the industry. The analysis of financial BSC indices for universities is not the subject of this research and is described in the article [12]. The current paper is connected with the study of the approaches to the creation of target indices of scientific and educational activity and the systems of informational support of the calculation of these indices and their analysis.

\section{MATERIALS AND METHODS}

For the specification of the target indices of the scientific, research and educational activity the study of the publications in the mentioned subject the lists of indices which are used in various higher educational institutions are selected. For the selection of an optimal platform for the construction of the system of information support of the management process by objectives the existing foreign and domestic products, and also the experience of the construction of such systems in the Russian higher educational institutes are analyzed. The way of the construction of the mentioned system in the Volgograd State University is described.

\section{RESULTS AND DISCUSSION}

\section{A. Directions of measurement of the activity of a higher educational institution}

In the Volgograd State University the following scientific and educational goals are set: development of research, development and innovation activity and also the provision of the correspondence of the content and quality of the training of the students and graduates to the requirements of the Federal State Educational Standard of Higher Education.

$$
\begin{aligned}
& B . \quad \text { Selection of the indicies of scientific and } \\
& \text { research acitvity }
\end{aligned}
$$

In source [13] the following elements of scientific and research activity in a university are suggested to take into consideration: implementation of scientific research, resource provision, approbation of results and the introduction of the results of the scientific research into real economic practice and into scientific and educational activity. The main instrument of progress in the authors' opinion is the plan of scientific and research of a chair. The structure of planning management of scientific and research work is suggested however specific measurable indices are not given. In the Volgograd State University the planning and reports of chairs are also used as a basic system of reporting. In the paper [6] the strategic tasks within the goal «Increase of importance of higher educational institution in the innovation development of a state» are the tasks «Increase of investment attractiveness of a region» and «Development of the scientific base of a higher educational institution». In paper [8] the following indices are taken as measurements characterizing the efficiency of scientific and research business process: number of innovation processes within scientific and research activity, post graduate training, post graduate training for the degree of doctor of sciences, dissertation boards. In Saint Petersburg State University the indices which characterize the scientific and research activity are «Volume of research and development calculated per one researcher», «Volume of research and development financed within international projects and grants» [10].

In the Volgograd State University the following development tasks are set for the development of scientific and research activity:

- Implementation of fundamental and (or) applied scientific research in scientific areas which correspond to the enlarged groups of specialist programs. The volume of financing of scientific and research work per one scientific and pedagogical worker is chosen as an efficiency index (A1).

- Increase of the number of scientific publications in the leading Russian and foreign scientific journals. The indices are as follows: number of scientific publications in the leading Russian and foreign journals indexed by Scopus (A2) and Web of Science (A3) calculated per 100 of researchers.

- Commercialization of results of scientific research of department employees. The indices are as follows: number of the concluded license agreements and contracts for the sale of intellectual products (A4) and also the volume of funds received from the management of the intellectual property rights (A5).

- $\quad$ Growth of training quality of the professor and educational staff. The indices are as follows: share of the lecturers in an educational program taking part in the scientific or scientific and methodic activity (upon scientific publications) (A6) and also the share of the students of the full time educational form, taking part in the scientific and research work on payable basis (A7). 


\section{C. $\quad$ Selection of the index of educational activity}

In the source [6] the increase of the competitiveness of higher educational institution and the improvement of the educational process are chosen as strategic tasks for the achievement of the goal of the growth of quality of educational services. In the paper [2] the indices which characterize the prospect "Clients" are chosen the following ones: «Number of applicants with a high school grade», «Number of students with excellence», «Number of students who found job within the specialization after the graduation». In the source [8] the indices which characterize the efficiency of the educational business process are chosen the following ratios: «Number of new educational programs», «Acceleration of the entrance of new innovation educational products of new innovation educational products». In Saint Petersburg [16] such indices are «Average grade of the Unified State Examination of the students enrolled after taking the Unified State Examination for Bachelor and Specialist programs at the expense of the corresponding budget of the budgetary system of the Russian Federation and with payment of education costs by individuals and legal entities», «Share of students enrolled in Master Programs from the total number of students», «Number of post graduate students in the university calculated per 100 students», «Share of educational standards which are realized and approved by the university in the total number of the standards that are being realized in the university», «Share of students taught upon the educational standards approved by the university in the total number of students», «Share of educational programs realized at distant education form in the total number of the realized educational programs», «Share of students which are taught upon the educational programs of distant form in the total number of students». The indices of international educational activity are shown separately: «Share of foreign professors and lecturers including the Russian citizens having the $\mathrm{PhD}$ in foreign universities in the total number of scientific and educational staff of the university», «Share of foreign students (including the students from CIS countries) which study in Bachelor, Specialist, Master programs in the total number of students», «Number of foreign students of the leading foreign universities who study in the university 1 month or more», «Number of educational programs of higher education and supplementary educational programs developed and realized in partnership with leading foreign higher educational institutions and organizations», «Share of students who study in educational programs of higher education of full time form who obtained support in the form of participation in the programs of international academic mobility within the total number of the students of full time educational program», «Share of scientific and educational staff of the university who took part in the programs of international academic mobility», «Number of foreign students and post graduate students who study within basic educational programs».

In the Volgograd State University the following tasks for the development of educational activity are set:

- Qualitative enrollment of first year students in educational programs (specialist programs) and forms of education. The indexes are: average grade of unified state examination enrolled for a state funded place in full time form of education (B1) and average grade for unified state examination of all the enrolled students in full time form of education (B2).

- Social and professional licensing of educational program. The index is the availability of the existing certificate of the professional and social licensing of educational program.

- Compliance of the basic education of professional and educational staff to the specification of the taught programs. The characterizing index is the share of professional and educational staff in educational programs, whose basic education does not correspond to the specificity of the taught discipline (B4).

- Change of the structure of chairs and laboratories taking into account the practical training of the students with the use of material and technical base of other organizations and enterprises. The characterizing index is the number of «basic» chairs and laboratories (B5).

- Increase of the role of educational work of foreign professors in the total educational work of the university chairs. The characterizing index is the share of educational work of foreign lecturers in the total number of work of the institutes (B6).

- Increase of the share of the students who graduated from Bachelor or Specialist Programs from other universities. The characterizing index is the share of students who graduated from other universities and enrolled in the list of first course students list from the total number of students enrolled in the first course in Master programs of full time education (B7).

- Increase of the share of foreign students. The characterizing index is the number of foreign students reduced to full time form of education (B8).

- Development of net forms of cooperation with other higher educational institutions at the implementation of educational programs. The characterizing index is the number of joint educational programs with other higher educational institutions (B9).

- Increase of share of the students in Master Programs and post graduate programs for training of science and pedagogical staff (B9).

\section{Analysis of platforms of informational support of management by objectives}

There exist a considerable number of platforms which can be used by higher educational institutions for informational support of management by objectives both for foreign and domestic students. Historically first foreign product of this category is the module «System of Decision Making Support» of the system «University» developed by company RedLab [14], which was used in 2000s in eight higher educational institutions (Russian State University of Oil and Gas, 
Belgorod State University, Saint Petersburg State Transport University, Volgograd State Technical University, Ural State University, National Research University Higher School of Economics, at the faculty of Computational Mathematics and Cybernetics of Moscow State University, Saint Petersburg State Electrical Engineering University).

For the present moment due to the obsolescence of the used platform of SAP ERP and the bankruptcy of company developer there are no new versions of the software in the market. The modern foreign software products are presented by the following programs: Andara Business Intelligence (http://andara.bi/), BSC Designer Online (https://ru.webbsc.com/) which are used in Ural Institute of Economics, Management and Law 15], Corporater (http://corporater.com), Clearpoint Strategy (https://www.clearpointstrategy.com/) and some others. The largest part of them presents an interface to the users which is constructed by the principle of a dashboard. The most functional from these programs have functional analysis of data including the Big Data (for instance with the use of Hadoop - Andara BI), budgeting, planning, management and efficiency of an enterprise (Corporater). Despite the presence of wide opportunities in the integration with systems sources of the data and any adaptation to the specificity of informational support of management by objectives in the universities of Russia and very often the localization of user interface in such systems does not exist. The largest part of them is presented as a service what has considerable risks under the condition of escalation of sanctions. Besides in compliance with the Decree of the Government of the Russian Federation adopted November, 162015 № 1326 and the Decree of the Ministry of Education and Science №P-282 adopted August, 152016 there exists the necessity to give preference to domestic program software which implements functions of informational support of management by objectives. The examples of use of domestic products developed for the realization of the management by objectives the KPI MONITOR Analyzer (http://www.kpimonitor.ru/about/overview), «1C:Management by Objectives and KPI» (http://solutions.1c.ru/catalog/kpi/features) can be mentioned. The latter product which is created on the platform «1C:Predpriyatiye (Enterprise)» architecturally has wide opportunities of the integration with systems in this platform which is widely used in higher educational institutions. This software is «1C: Universitet (University)», «1C: (Bukhalteriya gosudarstvennogo uchrezhdeniaya) Accounting of a state establishment», «1C:Zarplata i kadry (Salary and Staff)». The model «Strategicheskoye upravleniye universitetom» (Strategic Management of a University) for the system of business modeling Business Studio (http://www.businessstudio.ru/buy/models/model/model_strat egicheskoe_upravlenie_universitetom/) contains main prospects for the construction of a balanced system of indices. For every from these prospects (objectives) the main strategic goals of the university are specified. The indices and their target values are evaluated. However the integration opportunities of the system Business Studio can be assessed as modest ones. It is necessary to emphasize in particular the application «Personal Rector Account» (https://lkr.cbias.ru/login), developed by the company
Proscom which uses the system of the indices suggested by the Ministry of Education and Sciences and the data from internal systems of the ministry. It is also worth mentioning the system «Rector.Assistant» developed by the project office of Mari State University (panel.marsu.ru) organized as a customization over the bus line of the integration interaction with the systems «1C:Bukhalteriya gosudarstvennogo uchrezhdeniya (Accouinting of State Organization)», «ARBIS: Zarplata i upravleniye personalom (Salaries and Personnel Management)», «1C:Gosudarstvenniye i munitsipalnye zakupki (State and Municipal Purchases)» and «1C:Kombinat planovogo pitaniya (Facility of Planned Food Production)» и «BIT.Appetit». The drawback of the system is the absence for the present moment of the integration with the systems of management of educational process and the analysis of scientific and innovation activity. In the whole the conclusion about the absence of a ready made solution can be made which can be recommended to all higher educational institutions. Taking into account the specificity of internal accounting systems of higher educational institutions the implementation of integration project is indispensable. In Ivanovskiy State Power Engineering University named after V.I. Lenin the integrated information and analytical system of management consisting from eight sub systems constructed with the use of typical functional on the platform «1C:Predpriyatiye 8 (1C:Enterprise 8$) »$ is used. The system mentioned above is the basis for the quality management system the part of which is the system of multi criteria assessment of the efficiency of work of higher educational teaching personnel, of chairs and faculties by means of rating creation. The formed ratings are used in regulations of the assessment systems of activity efficiency [16].

\section{E. Experience of development of the system of informational support of management by objectives in the Volgograd State University}

In the Volgograd State University the development of an integrated solution on the platform «1C:Predpriyatiye 8 (1C:Enterprise 8)» is carried out. Within the goal of management by scientific and innovation activity in the system «1C: Universitet (University)» an additional functional dealing with the accounting of contracts for the implementation of scientific and research works [17] and scientific and technical measures what allows calculating the indices $\mathrm{A} 1$ and $\mathrm{A} 7$, and also the publications records [18] for calculation of indices A2, A3, A6 are used. In the system «1C: (Bukhalteriya gosudarstvennogo uchrezhdeniaya) Accounting of a state establishment» the record of license agreements and contracts for sales of intellectual property rights (A4) and also the record of funds obtained from the management of the intellectual property rights is carried out (A5). The source of the primary information for the management of the educational activity is the system «1C: Universitet (University)». For the calculation of indices B1, B2, B7, B8 the staff mechanisms of the sub system «Enrollment board» is used. The record of the availability of professional and social licensing (B3) is implemented with the help of the developed sub system «Informatsiya dlya saita (Information for the site)» [19] which is also used at the calculation of the index B3. For the record of indices connected with the training of personnel 
with higher qualification the product of the university development is used. The use of all functional in the first record of indices in platform «1C:Predpriyatiye (Enterprise)» allows solving integration goals and allows providing the assessment of indices.

\section{CONCLUSION}

The successful use of the management methodology by objectives allows a higher educational institution creating a precise specific position in the educational space of the region, consolidating and coordinating efforts of various actors, assisting to the inclusion of higher educational community into the adoption of strategic decisions [2]. The use of informational technologies allows implementing these processes quickly and effectively. The solution of these tasks allows influencing the innovation development of a region in the whole.

\section{Acknowledgment}

The research is financially funded by the Russian Fund for Fundamental Research and the Administration of Volgograd region, project «Financial and mathematic algorithms of the budgeting of structural subdivision of educational organizations» № 17-12-34015.

\section{References}

[1] Kalinina A., Borisova A., Barakova A. Development Efficiency Analysis of Public Administration Informatization. Proceedings of International Scientific and Practical Conference on Role of Integration and Clustering in Provision of Sustainable Economic Growth. Volgograd, MAR 17-19, 2016. Contributions to Economics. pp. 481-493

[2] Mineva O.K., Akmaeva R.I., Usacheva L.V. Realizatsiya strategii razvitiya universiteta na osnove postroeniya strategicheskoi karty [Implementation of the strategy of university development on the basis of the construction of strategic map]. Vestnik Saratovskogo gosudarstvennogo tekhnicheskogo universiteta [Bulletin of Saratov State Technical University], 2013, Vol. 1. № 1. pp. 297-304.

[3] Veretennikova O.B., Drantusova N.V., Klyev A.K., Kortov S.V., Maidannik V.I., Malysheva L.A., Popova L.N. Razrabotka strategii obrazovatel'nogo uchrezhdeniya: Metodicheskie rekomendatsii [Development of Strategy of an Educational Organization. Methodical recommendations]. Universitetskoe upravlenie: praktika $\mathrm{i}$ analiz [University management: practice and analysis], 2008, № 4, pp. 3-403.

[4] Drucker P., The Practice of Management, Harper, New York, 1954; Heinemann, London, 1955; revised edn, Butterworth-Heinemann, 2007

[5] Kaplan Robert S., Norton D. P. "The Balanced Scorecard - Measures That Drive Performance". Harvard Business Review, 1992, (JanuaryFebruary), pp. 71-79.

[6] Obolyaeva N.M. Sistema sbalansirovannykh pokazatelei kak element konkurentnoi strategii vuza [System of balanced indices as an element of competitive strategy of a higher educaitonal institution], Informatizatsiya obrazovaniya i nauki [Infomratisation of education and science], 2011, № 4(12), pp. 94-103. Available at: https://elibrary.ru/item.asp?id=17280943. Date of reference: 15.01 .2018

[7] Maltseva G.I., Lugovoy R.A., Soldatova Yu. A. Primenenie sistemy sbalansirovannykh pokazatelei $\mathrm{V}$ protsesse strategicheskogo planirovaniya vuza (na primere Vladivostokskogo gosudarstvennogo universiteta ekonomiki i servisa) [Use of the system of balanced indices in the process of strategic planning of a higher educational institution (on the example of Vladivostok State University of Economics and Service)], Universitetskoe upravlenie: praktika i analiz [University management: practice and analysis], 2004, № 5-6(33), pp. 96-103. Available at: http://ecsocman.hse.ru/data/267/567/1216/96-103.pdf. Reference date: 15.01 .2018
[8] Bilalov E.M., Kichikhanova P.M. Primenenie sistemy sbalansirovannykh pokazatelei $v$ vuze (na primere Dagestanskogo gosudarstvennogo universiteta) [Application of the system of balanced indices in a higher education institution (on the example of Dagestan State University)]. Fundamental'nye issledovaniya [Fundamental research], 2016, №2-3, pp. 472-476. Available at: https://elibrary.ru/item.asp?id=25621483. Reference date: 15.01 .2018

[9] Egorova E.M. Metodologicheskie osnovy sbalansirovannoi sistemy pokazatelei strategicheskogo razvitiya vuzov [Methodological bases of the balanced system of indices of strategic development of higher educational institutions]. Izvestiya Nizhnevolzhskogo agrouniversitetskogo kompleksa: nauka i vysshee obrazovanie [Bulletin of Nizhnevolzhsk agrouniversity complex: science and higher education], 2015, №3(39), pp. 204-212. Available at: https://elibrary.ru/item.asp?id=24318726. Reference date: 15.01 .2018

[10] Rechinskiy A.V., Chernenkaya L.V., Mager L.v., Matveeva E.V., Chernenkiy A.V. Razrabotka metodiki rascheta pokazatelei effektivnosti deyatel'nosti universiteta i ego strukturnykh podrazdelenii [Development of the methodology of the calculation of the indices of the work efficieny of the university and its structural sub divisions]. Sovremennye tekhnologii upravleniya [Modern technologies of managment], 2015, №6 (54). pp. 46-54. Available at: https://elibrary.ru/item.asp?id=23702743. Reference date: 15.01.2018

[11] Goryachko V.V., Kostrova V.N, Lyvovich I.Ya. Algoritmizatsiya vybora pokazatelei effektivnosti deyatel'nosti vuza dlya upravleniya ego polozheniem $\mathrm{v}$ reitingovoi sisteme [Algorythmization of the indices selection of the work efficieny of a higher educational institution for the management by its state in the ranking sytem]. Vestnik Voronezhskogo gosudarstvennogo tekhnicheskogo universiteta [Bulletin of Voronezh State Technical University], 2016, №6(12), pp. 68-72, Available at: https://elibrary.ru/item.asp?id=27467140. Reference date: 15.01.2018

[12] Filipenko N.V., Poluboyarov V.V. Vnedrenie sistemy finansovogo planirovaniya s ispol'zovaniem vnutrivuzovskoi informatsionnoi sistemy [Introduction of the system of financial planning with the use of an information system], Universitetskoe upravlenie: praktika i analiz [University management: practice and analysis], 2017, vol.21, №6(21) (accepted for publicatoin).

[13] Antropov V.A., Shelomentsev A.G. Planirovanie nauchnoissledovatel'skoi raboty na universitetskoi kafedre [Planning of scientific and research work at a university chair]. Universitetskoe upravlenie: praktika i analiz [University management: practice and analysis], 2015, $\begin{array}{llll}\text { №1, pp. } \quad 17-27 . \quad \text { Available } & \text { at: } \\ \text { http://www.umj.ru/index.php/files/download/788/. Reference date: }\end{array}$ 15.01.2018

[14] Smelyanskiy R.L., Ivenko M.V. Vozmozhnosti sistemy «Universitet» kompanii «REDLAB» dlya formirovaniya i realizatsii strategii razvitiya vuza [Opportunities of the system "University" of the company "Redlab" for the creation and implementation of the strategy of higher education development], Universitetskoe upravlenie [University management], 2004, № 3. p. 18-25. Available at: http://ict.informika.ru/ft/004061/smel_iev.pdf. Reference date: 15.01.2018

[15] Skripov A.V. Realizatsiya metodiki sistemy sbalansirovannykh pokazatelei s primeneniem programmy BSC Designer dlya negosudarstvennogo uchrezhdeniya vysshego obrazovaniya [Implementation of methodology of the system of balanced indices with the use of the program BSC Designer for non governmental organization of higher education]. Available at: http://ru.calameo.com/read/0048270428653e0e3657d. Reference date: 15.01.2018

[16] Tatarykin S.V., Ratmanova I.D., Golubitskiy E.M., Bulatov L.N., Bulatova E.E. Opyt organizatsii informatsionno-analiticheskogo soprovozhdeniya protsessa upravleniya $v$ IGEU [Experience of organization of information and analytical assistance of the process of management in the Ivanovo State Energetic University]. Vestnik Ivanovskogo gosudarstvennogo energeticheskogo universiteta [Bulletin of Ivanovo State Energetic University], 2015, №6, pp. 65-72, Available at: https://elibrary.ru/item.asp?id=25036065. Reference date: 15.01.2018

[17] Poluboyarov V.V., Kalinina A.E. Informatsionnaya sistema ucheta dogovorov na vypolnenie nauchno-issledovatel'skikh rabot kak element sistemy strategicheskogo upravleniya obrazovatel'noi organizatsiei 
[Information system of the record of the contracts for the implementation of scientific and research works as an element of the system of strategic management of a higher educational organization], Nauchnoe obozrenie [Scientific review], 2015,№ 24, pp. 271-280. Available at: https://elibrary.ru/item.asp?id=25602081. Reference date: 15.01.2018

[18] Poluboyarov V.V., Chernavin D.A. Upravlyaemaya ontologiei sistema analiticheskogo ucheta publikatsii sotrudnikov kak element podderzhki prinyatiya reshenii $\mathrm{v}$ obrazovatel'noi organizatsii [The system of analytical record of the publications of the employees of the university managed by ontology as an element of the support of the decision making in an educational institution]. Vestnik Volgogradskogo gosudarstvennogo universiteta. Seriya 3: Ekonomika. Ekologiya
[Bulletin of Volgograd State University. Series 3. Economy. Ecology], 2013, № 2 (23). pp. 115-123. Available at: https://elibrary.ru/item.asp?id=21098152. Reference date: 15.01 .2018

[19] Poluboyarov V.V. Sistema ucheta i publikatsii svedenii ob obrazovatel'nykh programmakh kak instrument informirovaniya o realizuemoi strategii upravleniya obrazovatel'noi organizatsiei [System of record and publication of information about educational programs as a tool of informing about the implemented strategy of management of educational organization], Innovatsionnyi Vestnik Region [Innovation Bulletin. Region], 2014, № 2. pp. 1-5. Available at: https://elibrary.ru/item.asp?id=21885883. Reference date: 15.01.2018 